\title{
Changes in the Role of Middle Manager: A Historical Point of View
}

\author{
L. Bañares Parera and A. M. Fernández-Vallejo
}

\begin{abstract}
Middle Management is now a reality in the business organizations, but there is, nevertheless, a lack of contextualization with respect to middle management in the history of management. This study will review the ideas of Taylor, Fayol, Mayo and Barnard -milestones in the history of organization- with the objective of highlighting what their contributions and limitations were concerning the advent of middle management. This research project shows that middle management is the natural result of a new organizational structure that originates in a knowledge society, shows the indispensable role played by middle managers today as a key element between management and lower levels of the organization, and demonstrates the need to provide them with specific training
\end{abstract}

Index Terms-History of management, innovation of management, middle manager, training of middle manager.

\section{INTRODUCTION}

Currently, the figure of the middle manager appears frequently in organizations. The concept of middle management is not at all well defined and the literature presents ambiguities [1]-[3]. Since the early twentieth century there have been many models and advances in organization theory and concerning how to govern organizations, but the focus and the object of study has always been the manager. That is, the theory of organization has been management theory and, on the practical side, the training of managers. For this reason this research will consider some models of organizations we consider more relevant within in the beginnings of theory of organization, aiming to analyze which characteristics have contributed to the role of the middle manager today. To resolve this issue we thought it appropriate to explore how the concept of the middle manager has evolved throughout the history of business organization theory.

It would go beyond the scope of our research to carry out a thorough analysis of all organization theorists, therefore, we will focus on the authors whose theories we consider capable of opening new avenues to understanding middle management, due both to the limits of their theories as well as to their contributions. In particular, we will focus on Taylor, Fayol, Mayo and, finally, Barnard; authors whose contributions represent a milestone in the history of

Manuscript received January 12, 2013; revised April 1, 2013.

Ana M. Fernández-Vallejo and Leticia Bañares Parera are with ISSAUniversity of Navarra, Spain (e-mail: amf@unav.es, lebanares@unav.es). organization and all of whom are previous to the postindustrial society or the knowledge society. As we see below, it will be in the knowledge society where we can fully find the role of the middle manager.

\section{F. W. TAYLOR (1856-1915): "THE FUNCTIONAL SUPERVISOR"}

In Taylor's theory [4] we will focus on the supervisor's functions. Taylor's main concern was to increase productivity in the company; this problem, he said, was partially due to the fact that workers were slow and ineffective and lacked method in performing their tasks. Another factor that influenced lack of productivity was that employers were unaware of the time required to perform their tasks and, therefore, the control of tasks often became somewhat arbitrary, often causing rivalries and conflicts. This makes it difficult to achieve homogeneous production and creates serious problems within the organization.

Influenced by the rationalist positivism of the day, Taylor proposed a rationalization of all productive activities so that homogeneous production could be achieved. To do this, the most competent worker must be chosen and his task movements must be broken down to verify whether the time required for each movement and the number of movements involved was strictly necessary. Thus, this worker's behaviour became standard and was presented to other workers as a model, the one best way; hence the behaviour presented to the workers was a purely technical form of learning.

This model of performance implied separating formulation from execution for each job and establishing a division between the various stages of implementation. Moreover, putting the "one best way" into practice required the "functional supervision" of each task and several supervisors were needed, each one specialized in a particular area with the functional authority relative to only one task. Taylor sought to establish a control structure capable of ensuring maximum rationality and efficiency. The supervisor's role was only to insure that the worker adapted his/her movements to the standard model set.

This functional supervisor, in the sense that they oversaw subordinates, may appear as a first middle manager, but the fact that their task was reduced solely to control, reduced their role to that of a mere executor according to a mechanical model of workers and their work; a role in which there was no possibility of making any contribution. That is, the "perfectioning" to which Taylorism aspired follows a "technical" model: it was not the result of the worker's intervention as a person. In summary, the human 
factor was not considered in Taylorism and organization acquires the static and rigid characteristics of a large machine.

\section{H. FAYOL (1841-1925): PRINCIPLES RATHER THAN RULES}

In regards to the theory of formal organization, we are going to focus on principles of authority and initiative. Fayol [5] determined that in a business organization there are various activities and, in particular, the task of management has a specific character and, therefore, should not be something left to a technician. So with this author a concept of administration different than Taylor's appears: management does not consist of a purely technical planning and control of the workplace, or of the rigid application of a set of operating rules, but rather of know-how. Fayol [6] thinks that the science of management is not confined to the rigid application of certain rules because he observed the contingent and unique character of human acts. In fact, he uses the term "principles" rather than "rules ${ }^{1 "}$. It would be worth clarifying the distinction between rules and principals: rules implicate one single way of practicing while principles are just an orientation that allows one to bear in mind certain concrete conditions and circumstances. There are fourteen principles Fayol refers to and we will focus on those we consider the most relevant in order to help us understand how the role of the middle manager appears: these are the principles of authority and initiative.

The authority principle also represents an advance in two particular aspects. First, because it makes a distinction between "official authority," that which is derived from the position, and "personal authority," which, according to Fayol, consists in personal intelligence, experience, moral courage, managerial ability and previous experience. This distinction opens up a wider concept of authority: authority is given to us not only as a function of a position held, but is somehow related to personal qualities and, therefore, can occur at any level in the organization.

The initiative principle consists, according to the author, in the power to make decisions and implement them, that is, it generates a framework of freedom that grants the worker, regardless of the level he/she occupies in the chain, a decision-making margin. However, Fayol realizes that it is an arduous task - for the top manager - to maintain and inspire the initiative of all workers without overstepping the limits set by authority. In effect, promoting the initiative of all workers implies taking risks, but at the same time it represents a different way of understanding managerial tasks and deserves considerable attention in order to explain the behaviour of the middle manager ${ }^{2}$.

\section{E. MAYO (1880-1949): “THE INFORMAL LEADER"}

\footnotetext{
1"I will prefer to use the word 'principles,' stripping it of any notion of rigidity. There is nothing rigid or absolute in administrative matters, it's all a matter of degree. The same principle is almost never applied twice in identical conditions" [5].

${ }^{2}$ On the other hand, the exchange of information, as well as initiative, implies a degree of trust between the two [2].
}

Within the Theory of Human Relations we are going to analyze the figure of informal leader. Human Relations School $^{3}$ arose as a result of the conclusions reached by the group of Harvard professors that had participated in the Hawthorne studies. They realized that other factors appeared - psychological and social - that had a great influence on productivity and had not been taken into account up to that point in time.

The research at Hawthorne showed the tendency people have to form or belong to a workgroup and the satisfaction they derive from it. People were no longer regarded as an isolated and unique unit. The unit becomes the group. Mayo [7] observed that for the individual, groups are an integrating factor, a means to reduce the monotony of work, a communication channel, an opportunity to earn prestige and, most importantly, a factor that increases job security ${ }^{4}$. The existence of these informal groups led him to focus his studies on what later would be called the "informal organization." These informal groups led him to discover the importance of interpersonal relationships that arise spontaneously in the workplace, and this is what was subsequently called informal organization.

Mayo mentions that there will be one group member that stands out, one who becomes the "leader" of the group and sets standards of behaviour that are accepted and adopted by the others, a sort of informal leader. Although this figure may initially evoke what will later be called middle management, this figure cannot be identified as such because, in the first place, the informal leader is just another member of the group that has taken on a role that has not been assigned by top management and for which he/she has no special training; and, in the second place, because the groups Mayo refers to are small groups that are only united by a series of common tasks and, consequently, because his/her viewpoint is very limited and his/her interests are solely those of the group to which he/she belongs, without regard for the organization's goals. However, in our view, the current role of the middle manager is linked more to formal organisation given that the role does not emerge spontaneously but has, instead, been established in advance.

\section{CH. I. BARNARD (1886-1961): TWO-WAY COMMUNICATION}

In the fourth place, we will review some aspects of $\mathrm{Ch}$. Barnard's thinking [8]. We are aware of the depth and complexity of his theory and will thus confine our explanation to the key aspects in understanding the figure of the current middle manager. The organization, for Barnard, is a kind of human cooperation; conscious, deliberate, and oriented to the attainment of a certain purpose. Consequently, in Barnard's theory, communication becomes a key element.

This represents an important innovation because communication within organization was previously

\footnotetext{
${ }^{3}$ Mayo was the founder of Human Relations School.

${ }^{4}$ Although the evaluation of group membership has been a positive contribution, Mayo gives undue importance to groups to the point that he calls into question individual freedom.
} 
understood only as a formal channel, yet this way it takes on two forms: descending communication, which corresponds mainly to formal communication, and ascending communication, which would originate in an informal manner from any member of the organization to the managers. Barnard realizes that the role a member plays in the organization is as real as the influence their qualities and character has in fulfilling this role. Barnard concludes that they must be complementary aspects in the study of organizational behaviour. Therefore, Barnard argues that it is necessary to ensure the existence of informal organizations in order to reduce the need for formal decisions and to promote the interactions that help to achieve the objectives of the organization. That is, Barnard's success is not the discovery of formal organization or of informal organization, but the affirmation that they are inseparable ${ }^{5}$.

Another issue that we cannot overlook is how Barnard refers to the issue of authority in relation to communication: Barnard argues that authority is what links communication with the willingness of individuals to cooperate, because authority depends as much on a cooperative attitude from the organization's staff members as it does on the communication system. Regarding the objective nature of authority, Barnard [8] establishes a distinction of interest that refers to the authority of position, which is what an individual has "merely because of the advantage of his position," and managerial authority, which is attributed to certain individuals for their superior ability - knowledge, intelligence - regardless of their position ${ }^{6}$.

In this sense, Barnard believes that one of the main functions of managers is to serve as a channel of communication which facilitates the coordination of the activities of other members within the organization. This first managerial task - to serve as a channel of communication - involves loyal behaviour at all levels: loyalty is "the first necessity, because the lines of communication cannot function at all unless the personal contributions of executives are present at the required positions, at the times necessary, and without default for ordinary personal reasons" [8]. Secondly, Barnard considers it necessary to ensure informal organization, whose functions are, among others, to reduce the need for formal decisions and to promote to a maximum the interactions that agree with the assignment of formal responsibilities. In this sense, it must be made clear, as will be discussed later, that the communication of middle managers with superiors is more than just spontaneous communication; the role assumed by the middle manager in current organizations involves a feedback between middle manager and top manager that is necessary to enrich the managerial strategic vision [9].

Another function assigned to management is the formulation of goals and objectives which, although

\footnotetext{
${ }^{5}$ In Barnard's thinking, social factors that influence organizations are not established in connection with membership of a group as stated by Mayo, but rather any interaction originates in a spontaneous way among members of the organization.

${ }^{6}$ In this respect, one sees a certain resemblance to the distinction made by Fayol between formal authority and personal authority, which in turn can be linked to the figure of the middle manager.
}

primarily the task of managers, should not be limited to them. One of the major difficulties for the functioning of organizations is to transmit to lower staff levels the organization's general goals and major decisions. This is the only way members will remain united and capable of being coherent with respect to final and detailed decisions. Consequently, managers need to "understand the concrete conditions and the specific decisions of the "ultimate" contributors from which and from whom executives are often insulated" [8]. The importance of ascending and descending communication is noted once again so that all the organization's members have in mind the organization's goals and, in this sense, middle management will be a fundamental channel.

\section{CONCLUSION: THE MidDle MANAGER}

After this brief tour of the history of the beginning's organization's theory, we are now in a position to make a first approximation to what is meant by middle manager. As we have already seen, one of the most important and relevant contributions is that of Barnard's considering the organisation as a cooperative system in which formal and informal organisation are inseparable and in which both ascending and descending forms of communication play a fundamental role. This framework will help us to understand the current role of the middle manager as we will now see.

We can say that the current middle manager requires not so much a specific management model as an organizational model, where the relationship between manager and employee has been restructured. The middle manager is not the result of management understanding and an acceptance of the need to delegate, but rather it supposes belonging to an organization understood as cooperation; this way, the company is understood as a set of people who strive to achieve a common goal through contributions that are personal and different for each member. In the knowledge society, as Drucker points out, "the management of knowledge workers must be based on the assumption that the corporation needs them more than they need it" [10] But for true cooperation, mutual understanding is necessary, which in turn requires communication. Descending communication - managerial communication of the organization's objectives and goals to other members - is not enough and, instead, according to Drucker [11] communication "should begin with the supposed recipient of the communication rather than the issuer." And in this sense the middle manager, as a formal communication channel, plays a fundamental role within the organization.

On the other hand, the middle manager is only possible in a type of organization in which positions have a margin of managerial work and operational work ${ }^{7}$, where the proportion of managerial work increases with increasing responsibility within the operation of the organization:

\footnotetext{
${ }^{7}$ It is useful to introduce two concepts developed by Llano [19] here. This author defines managerial work as that which does not follow fixed rules and whose outcome is uncertain, while operational work is that which follows known fixed rules and for which the results, supposing the rules are followed, are at least statistically secure.
} 
"knowledge workers expect to make the decisions pertaining to their own field" [11]. From this consideration, the middle manager becomes a key player with a high degree of responsibility derived from their strategic place within the organizational structure, since they know both the day-to-day activity and the organization's strategy [12].With this perspective it might appear that middle management is just a vertical mediator between management and operational levels; but this view must be complemented by identifying middle management also as a horizontal integrator that ensures the distribution of knowledge throughout the organization [13], [14]. What in previous organizational models had caused estrangement or conflict, in this new model of organization, and thanks to the middle manager, can become complementary [15], [16].

From these coordinates it is clear that this new model of organization is the result of what has been called a knowledge society: the middle manager requires specific training; a fact that, until recently, had not been observed [17]. Training becomes particularly necessary when one considers that the middle manager acts as a catalyst for two interlocutors with different training, functions, motivation and information: on one side the manager, and, on the other, the frontline worker [18].

In conclusion, this review has sought to highlight the main features and functions of middle management through various contributions to organization theory. It provides a new perspective on the middle manager insofar as it approaches the middle manager through a historical perspective and thus new topics for further research remain open.

\section{REFERENCES}

[1] P. Osterman, The Truth about Middle Managers: Who They Are, How They Work, Why They Matter, Boston: Harvard Business School Press, 2008.

[2] M. L. Raes, M. G. Heijltjes, U. Glunk, and R. A. Roe, "The interface of the top management team and middle managers: a process model," Academy of Management Review, vol. 36, no. 1, pp. 102-126, Jan. 2011.

[3] W. T. Schmid and S. W. Floyd, "The middle management perspective on strategy process: contributions, synthesis, and future research," Journal of Management, 2008, vol. 34, no. 6, pp. 1190-1221.

[4] W. Taylor, Principles of Scientific Management, New York: Norton, 1967.

[5] H. Fayol, Administración Industrial y General: Previsión, Organización, Mando, Coordinación, Control, Barcelona: Orbis, 1983.

[6] L. D. Parker and P. A Ritson, "Revisiting fayol: anticipating contemporary management," British Journal of Management, vol. 16 , no. 3 , pp. 175-194, 2005

[7] E. Mayo, The Human Problems of an Industrial Civilization, Salem: Ayer Publishing, 1977.
[8] Ch. I. Barnard, The Functions of the Executive, London: Oxford University Press, 1973.

[9] L. Rouleau and J. Balogun., "Middle managers, strategic sensemaking, and discursive competence," Journal of Management Studies, vol. 48, no. 5, pp. 953-983, July 2011.

[10] P. F. Drucker, La Empresa en la Sociedad que Viene, Barcelona: Urano, 2003.

[11] P. F. Drucker and M. I. Merino, El Management del Siglo XXI, Barcelona, Edhasa, 2000.

[12] I. Nonaka, "A dynamic theory of organizational knowledge creation," Organization Science, vol. 5, pp. 14-37, Feb. 1994.

[13] L. A. Costanzo and V. Tzoump, "Enhancing organisational learning in teams: has the middle manager got a role?" Team Performance Management, vol. 14, no. 3, pp.146-164, 2011.

[14] I. Kraut, P. R. Pedigo, D. D. McKenna, and M. D. Dunnette, “The role of the manager: what's really important in different management jobs," Academy of Management Executive, vol. 19, no. 4, pp. 122-129, Nov. 2005.

[15] G. Currie and S. J. Procter, "The antecedents of middle managers' strategic contribution: the case of a professional bureaucracy," Journal of Management Studies, vol. 42, no. 7, pp. 1325-1356, Nov. 2005.

[16] Q. N. Huy, "Emotional balancing of organizational continuity and radical change: the contribution of middle managers," Administrative Science Quarterly, vol. 47, no. 1, pp. 31-69, March 2002.

[17] Q. N. Huy, "In praise of middle manager," Harvard Business Review, vol. 79, no. 8, pp. 72-79, 2001.

[18] C. Llano, Humildad y liderazgo: ¿Necesita el Empresario ser Humilde? México: Ediciones Ruz, 2004.

[19] C. Llano, J. A. Pérez López, G. Gilder, and L. Polo, La Vertiente Humana del Trabajo en la Empresa, Madrid: Rialp, 1990, pp. 19.

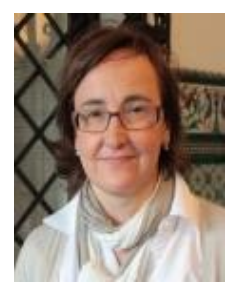

Leticia Bañares Parera is living in Barcelona (Spain). He is an assistant professor at the University of Navarra and Doctor of Philosophy from the University of Navarra. He is a Member of the "Institute of Anthropology and Ethics" at the University of Navarra and Associate Member of the Institute "Enterprise and Humanism" at the same university. Her research has focused on Anthropology and Organizational Behaviour. She has published La cultura del trabajo en las organizaciones, Madrid, Spain: Rialp, 1994, as well as articles in professional journals. She has also worked on projects concerning human resources and human development in the exercise of professional activities. Currently a professor at ISSA where she teaches courses in anthropology, Ethics and Organizational Psychology. Email: lebanares@unav.es

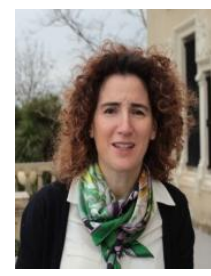

Ana M. Fernández-Vallejo is living in Tudela (Spain). She obtained her PhD in Classics from the University of Navarra. She has taught at the School of Humanities and Social Sciences of the University of Navarra for 7 years. Currently she is an assistant professor in ISSA-School of Management Assistance, where she teaches subjects related to the area of Communication in Business and Spanish as a foreign language. Her areas of research include new technologies related to the world of education and communication in Business, as well as Spanish for specific purposes 